\title{
PENINGKATAN HASIL BELAJAR AKIDAH AKHLAK MATERI IMAN KEPADA MALAIKAT MELALUI MODEL NUMBERED HEAD TOGETHER PADA SISWA KELAS VII B MADRASAH TSANAWIYAH NEGERI 4 PASER
}

\author{
SUGITA \\ MTs Negeri 4 Paser, Kalimantan Timur \\ e-mail:sugitoutomo2@gmail.com
}

\begin{abstract}
ABSTRAK
Penelitian ini di latar belakangi oleh masih rendahnya hasil belajar siswa kelas VII Madrasah Tsanawiyah Negeri 4 Paser mata pelajaran Akidah Akhlak Penelitian ini bertujuan untuk mengetahui : Adakah peningkatan prestasi belajar peserta didik pada pembelajaran Akidah Akhlak materi Iman Kepada Malaikat melalui model Numbered Head Together di Madrasah Tsanawiyah Negeri 4 Paser Tahun Pelajaran 2019/2020. Dengan model ini mempermudah mudah guru untuk merangsang keaktifan peserta didik melalui pemberian tugas atau pertanyaan yang dikerjakan oleh peserta didik secara bersama-sama dalam kelompok kecil. Guru juga mudah memantau aktivitas peserta didik sehingga tingkat kesukaran dan permasalahan yang dihadapi oleh peserta didik dapat diketahui dan dicarikan solusinya oleh guru.Hasil dari penelitian menunjukkan bahwa model pembelajaran Numbered Head Together dapat meningkatkan hasil belajar siswa. Dapat dilihat dari hasil analisis data mulai dari pra siklus dengan rata-rata 71,3 dengan presentasi ketuntasan $41 \%$. Pada siklus I dengan rata-rata 77,4 dengan presentase ketuntasan $76 \%$ dan siklus II meningkat menjadi rata-rata 85.40 dengan presentase ketuntasan 97\%. Maka dengan demikian dapat di ambil kesimpulan bahwa penerapan model Numbered Head Together dapat meningkatkan hasil belajar Aqidah Akhlak materi Iman Kepada Malaikat pada siswa kelas VII B Madrasah Tsanawiyah Negeri 4 Paser Tahun Pelajaran 2019/2020.
\end{abstract}

Kata Kunci:Model Numbered Head Together, Hasil belajar siswa

\section{PENDAHULUAN}

Belajar sebagai suatu proses, ditandai dengan adanya perubahan pada diri seseorang. Perubahan sebagai hasil proses belajar dapat ditunjukkan dengan berbagai bentuk, seperti perubahan dalam pengetahuan, sikap dan ketrampilan. Perubahan ini memang dapat diamati dan berlaku dalam waktu relatif lama. Perubahan yang relatif lama tersebut disertai dengan berbagai usaha seperti membaca, pengamatan, eksperimen dan lain sebagainya. Berdasarkan pendapat di atas, pada intinya belajar merupakan suatu proses untuk mencapai suatu tujuan yaitu perubahan kearah yang lebih baik. Perubahan tersebut adalah perubahan pengetahuan, pemahaman, keterampilan dan sikap yang bersifat menetap. Belajar merupakan suatu efektifitas jiwa yang sadar akan tujuan.Tujuan adalah terjadinya sesuatu perubahan dalam diri individu. Perubahan yang dimaksud tentu saja menyangkut semua unsur yang ada pada diri individu. Maka seseorang dinyatakan melakukan kegiatan belajar, setelah ia memperoleh hasil, yakni terjadinya perubahan tingkah laku, misalnya dari tidak tahu menjadi tahu, dari tidak mengerti menjadi mengerti dan lain sebagainya. Kemudian secara istilah, prestasi belajar adalah "terjadinya perubahan tingkah laku pada diri peserta didik yang mencakup bidang kognitif, afektif dan psikomotor"'Sudjana, 2006: 3).Untuk mengetahui hasil belajar yang merupakan kemampuan yang diperoleh peserta didik melalui proses pembelajaran yang dilaksanakan dengan baik, sehingga peserta didik akan mengalami perubahan-perubahan kearah yang lebih baik. Misalnya dari semula yang tidak bisa menjadi bisa. Selain itu, dengan dilakukannya evaluasi atau penilaian ini dapat dijadikan feedback atau tindak lanjut, atau bahkan cara untuk mengukur tingkat penguasaan siswa (Susanto, 2012: 5).Pengukuran hasil belajar ini dapat dilakukan melalui tes atau dari pertanyaan-pertanyaan setelah selesainya materi pelajaran, yang bertujuan untuk meningkatkan daya ingat siswa. Melalui tes ini 
kemampuan masing-masing dari siswa dapat dilihat, apakah sudah memenuhi kriteria yang ditetapkan atau belum, dan dapat menunjang dari belajar itu sendiri.

Tujuan Mata Pelajaran Akidah Akhlak di Madrasah Tsanawiyah bertujuan untuk membekali peserta didik agar: a). Menumbuh kembangkan Akidah melalui pemberian, pemupukan, dan pengembangan pengetahuan, penghayatan, pengamalan, pembiasaan, serta pengalaman peserta didik tentang Akidah Islam sehingga menjadi manusia muslim yang terus berkembang keimanan dan ketakwaannya kepada Allah SWT. b). Mewujudkan manusia Indonesia yang berakhlak mulia dan menghindari akhlak tercela dalam kehidupan sehari-hari baik dalam kehidupan individu maupun sosial, sebagai manifestasi dari ajaran dan nilai-nilai Aqidah Islam (Peraturan Menteri Agama Republik Indonesia Nomor 2, 2008: 21).

Kondisi proses belajar mengajar Akidah Akhlak yang ada di MTs Negeri 4 Paser ,masih diwarnai dengan model belajar satu arah (ceramah) sehingga tidak merangsang peserta didik untuk terlibat secara aktif dalam proses belajar mengajar sehingga membosankan. Padahal model belajar Numbered Head Together ini memandang bahwa keberhasilan dalam belajar bukan semata-mata harus diperoleh dari guru, melainkan bisa juga dari pihak lain yang terlibat dalam pembelajaran itu, yaitu teman sebaya. Dalam penerapan model pembelajaran kooperatif tipe Numbered Head Together pada mata pelajaran Aqidah Akhlak, peserta didik lebih mudah menemukan dan memahami konsep-konsep yang sulit apabila mereka saling mendiskusikan masalah-masalah tersebut dengan temannya, keterlibatan peserta didik dalam pembelajaran dan memberi kesempatan pada peserta didik untuk mengungkapkan pendapatnya. Penerapan modelNumbered Head Together ini pada mata pelajaran Aqidah Akhlak dengan sendirinya akan menggerakkan aktivitas belajar peserta didik yang akan berdampak positif pada nilai kognitif.Model Pembelajaran Kooperatif Numbered Head Together.

Kelebihan Model Pembelajaran Kooperatif Numbered Head Together, di antaranya adalah: a). Peserta didik dilibatkan dalam pembelajaran secara aktif Dipilihnya model belajar Numbered Head Together diterapkan pada mata pelajaran Aqidah Akhlak karena cocok untuk memperhatikan tujuan dari pelajaran tersebut di antaranya yaitu untuk menumbuhkan dan meningkatkan keimanan peserta didik yang diwujudkan dalam akhlaknya yang terpuji, melalui pemberian dan pemupukan pengetahuan, penghayatan, pengamalan serta pengalaman peserta didik tentang Akidah dan Akhlak Islam. Untuk menunjang tercapainya tujuan Aqidah Akhlak tersebut harus didukung oleh iklim pembelajaran yang kondusif di antaranya peserta didik harus dilibatkan dalam kegiatan belajar mengajar b). Mengoptimalkan tutor sebaya Keberhasilan belajar menurut model belajar Numbered Head Together ini bukansemata-mata ditentukan oleh kemampuan individu secara utuh, melainkan perolehan belajar itu akan semakin baik apabila dilakukan secara bersama-sama dalam kelompok-kelompok belajar kecil yang terstruktur dengan baik. Melalui belajar dari teman yang sebaya dan di bawah bimbingan guru, maka proses penerimaan dan pemahaman peserta didik akan semakin mudah dan cepat terhadap materi yang dipelajari c). Menumbuhkan rasa kebersamaan. Disamping itu, suasana belajar dan rasa kebersamaan yang tumbuh dan berkembang di antara sesama anggota kelompok memungkinkan peserta didik untuk mengerti dan memahami materipelajaran dengan lebih baik. Proses pengembangan kepribadian yang demikian, juga membantu mereka yang kurang berminat menjadi lebihbergairah dalam belajar. Peserta didik yang kurang bergairah dalam belajar akan dibantu oleh peserta didik lain yang mempunyai gairah lebih tinggi dan memiliki kemampuan untuk menerapkan apa yang telah dipelajarinya

Kekurangan dari model pembelajaran kooperatif tipe Numbered Head Together, di antaranya adalah: a). Suasana pembelajaran bisa menjadi tidak kondusif jika guru tidak bisa mengelola kelas dengan baik.b). Kondisi kelompok akan stagnan jika tidak ada peserta didik yang bisa menjadi leader dan memiliki kemampuan lebih dibanding teman temannya. Oleh karena itu, guru perlu memperhatikan kondisi kelompok yang homogen misalnya dalam satu kelompok harus ada minimal satu peserta didik yang memiliki kemampuan di atas rata-rata. c). Kemungkinan ada peserta didik yang hanya mengikuti pendapat temannya tapi tidak 
benar-benar memahami materi. Oleh karena itu, guru perlu mengecek pemahaman peserta didik satu persatu.

Efektifitas Model Pembelajaran Kooperatif Tipe Numbered Head Together Dalam Meningkatkan Prestasi Belajar Aqidah Akhlak. Pembelajaran kooperatif merupakan strategi pembelajaran yang mengutamakan adanya kerjasama antar peserta didik dalam kelompok untuk mencapai tujuan pembelajaran. Para peserta didik dibagi ke dalam kelompokkelompok kecil dan diarahkan untuk mempelajari materi pelajaran yang telah ditentukan. Tujuan dibentuknya kelompok kooperatif adalah untuk memberikan kesempatan kepada peserta didik agar dapat terlibat secara aktif dalam proses berpikir dan dalam kegiatankegiatan belajar. Dalam hal ini sebagian besar aktifitas pembelajaran berpusat pada peserta didik, yakni mempelajari materi pelajaran serta berdiskusi untuk memecahkan masalah. Pembelajaran kooperatif merupakan strategi pembelajaran yang mengutamakan adanya kerjasama antar peserta didik dalam kelompok untuk mencapai tujuan pembelajaran. Para peserta didik dibagi ke dalam kelompok-kelompok kecil dan diarahkan untuk mempelajari materi pelajaran yang telah ditentukan oleh guru dalam proeses belajar mengajar.

\section{METODE PENELITIAN}

Rancangan penelitian ini dengan mengunakan model Penelitian Tindakan Kelas (PTK), Karena model penelitian ini adalah penelitian yang dilakukan oleh guru di dalam kelasnya sendiri melalui refleksi diri, yang bertujuan untuk memperbaiki kinerjanya sebagai guru, sehingga proses pembelajaran dapat berjalan dengan baik dan hasil belajar siswa meningkat (Uno, dkk: 2011: 41). Untuk lebih jelas berikut ini dikemukakan Tahapan-tahapan Pelaksanaan Penelitian Tindakan Kelas (PTK) menurut Arikunto (2006: 16)

a. Perencanaan

Langkah pertama adalah melakukan perencanaan secara matang dan teliti. Dalam perencanaan PTK terdapat tiga kegiatan dasar, yaitu identifikasi masalah, merumuskan masalah, dan pemecahan masalah.Pada masing-masing kegiatan, terdapat sub-sub kegiatan yang sebaiknya dilaksanakan untuk sempurnya tahap perencanaan. Rancangan yang dilakukan adalah:1).Membuat Rencana Pelaksanaan Pembelajaran. 2).Menyiapkan materi Aqidah Akhlak materi iman kepada malaikat 3).Merencanakan tindakan dengan ilustrasi PTK anatara Guru dan Peneliti sebagai mitra kolaboratif, dengan menerapkan model pembelajaran Numbered Head Together pada mata pelajaran Aqidah Akhlak.4).Menyusun jadwal kegiatan penelitian tindakan kelas (PTK) 5).Membagi peserta didik ke dalam beberapa kelompok yang terdiri dari 5 anggota dan tiap anggota diberi nomor 1-5 sesuai jumlah anggotanya. 6).Membuat lembar soal pretest untuk mengetahui daya serap siswa dalam pembelajaran. 7).Membuat lembar soal ulangan atau posttest untuk mengetahui hasil belajar setelah melakukan penilaian

b. Pelaksanaan

Tahap kedua dari PTK adalah pelaksanaan. Pelaksanaan adalah menerapkan apa yang telah direncanakan pada tahap satu, yaitu bertindak di kelas. Hendaknya perlu di ingat bahwa pada tahap ini, tindakan harus sesuai dengan rencana, tetapi harus terkesan alamiah tanpa di rekayasa. Hal ini akan berpengaruh dalam proses refleksi pada tahap empat nanti agar hasilnya dapat di sinkronkan dengan maksud semula. Ttindakan yang dilakukan peneliti adalah pelaksanaan pembelajaran Aqidah Akhlak materi iman kepada malikat model Numbered Head Together. Tindakan ini dilaksanakan dengan tiga tahap yaitu tahap pendahuluan, tahap inti, dan tahap penutup.

c. Observasi

Tahap ketiga PTK adalah pengamatan (observasing). Supardi dalam bukunya Suyadi (2010: 63) bahwa yang dimaksud pada tahap III adalah pengumpulan data. Dengan kata lain, observasi adalah alat untuk memotret seberapa jauh efek tindakan telah mencapai sasaran. Kegiatan observasi ini dilakukan selama proses belajar mengajar, untuk mengetahui aktivitas belajar siswa selama pembelajaran Akidah Akhlak. Selama proses 
belajar mengajar berlangsung, peneliti melakukan pengamatan terhadap kegiatan siswa dalam pembelajaran menggunakan lembar observasi. Adapun aspek pengamatan yang diamati adalah aspek keaktifan siswa, perhatian siswa, kedisiplinan siswa dan penugasan siswa.

d. Refleksi

Refleksi adalah kegiatan untuk mengemukakan kembali apa yang telah dilakukan. Refleksi sering disebut dengan istilah memantul. Dalam hal ini, peneliti seolah memantulkan pengalamannya, baik kelemahan dan kekurangannya.Refleks di laksanakan setelah tindakan berakhir, yaitu diakhir proses pembelajaran. Sebelumnya, guru melakukan analisis mengenai hasil tes dan observasi. Hasil analisis tersebut di gunakan untuk mengetahui hasil belajar hasil belajar siswa dalam pembelajaran tersebut. Berdasarkan analis data-data yang diperoleh, dilakukan refleksi terhadap pembelajaran. Jika ada kelebihan dalam pembelajaran maka kelebihan tersebut harus dipertahankan dan jika permasalahan selama pembelajaran haruslah dicarikan pemecahannya. Permasalahan tersebut dianalisa dan dilakukan perbaikan pada siklus berikutnya. Disamping hal tersebut hasil belajar siswa belum mencapai target atau indikator yang diinginkan. Sementara itu, diliat dari segi observasi siswa masih ada yang belum menunjukkan sikap positif. Hal ini terbukti dengan adanya siswa yang masih bermain-main dan berbicara sendiri saat melakukan strategi Numbered Head Together. Setelah melakukan tahapan-tahapan pembelajaran pada siklus penelitian, maka akan diketahui beberapa hal yang berkaitan dengan perubahan aktifitas belajar siswa selama pembelajaran, yaitu tentang peningkatan belajar Akhidah Akhlaq materi iman kepada malaikat dengan metode Numbered Head Together.

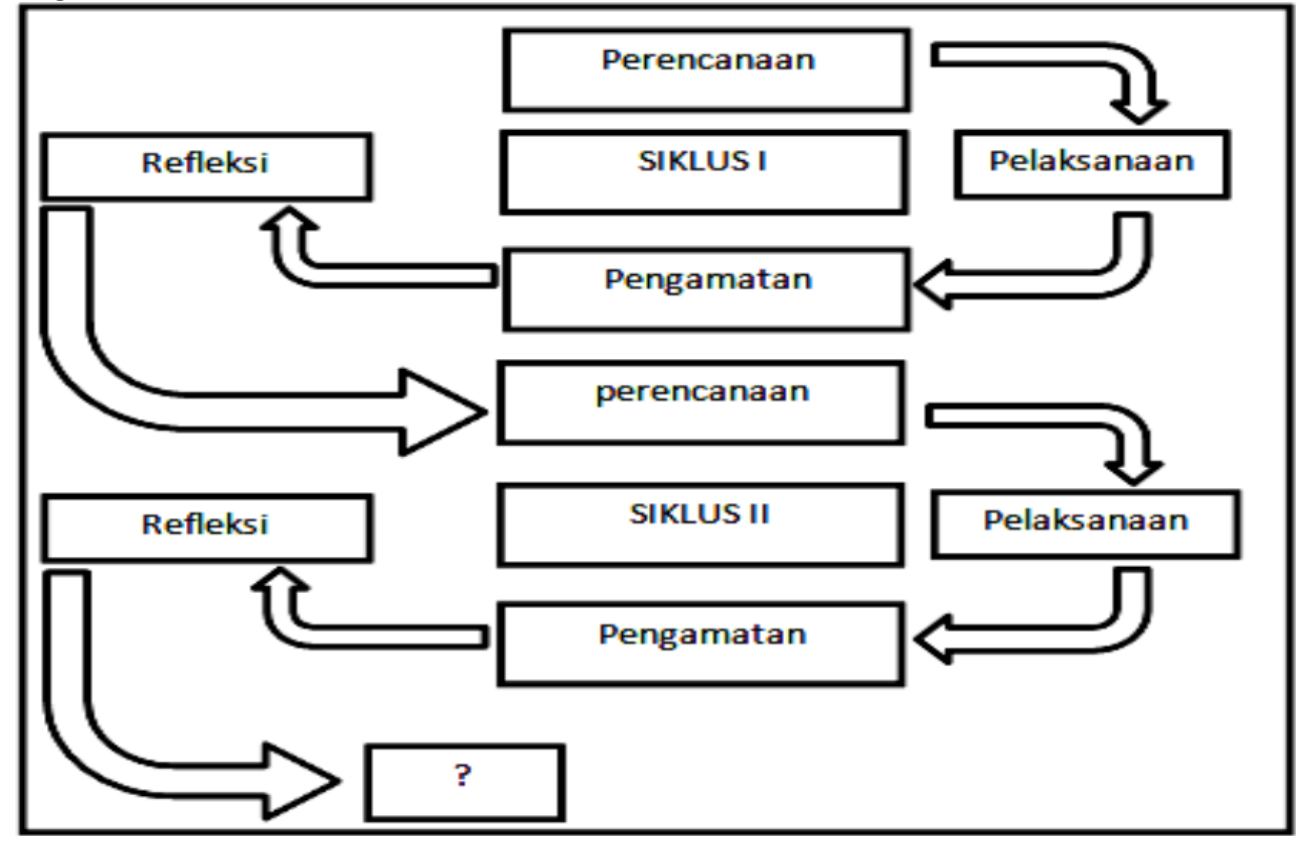

Gambar 1.Tahapan Pelaksanaan Penelitian Tindakan Kelas (PTK)

Instrumen yang digunakan dalam penelitian ini yakni a).Lembar Observasi berupa lembar data yang digunakan untuk mencatat kegiatan pembelajaran yang telah dilakukan. Dengan lembar observasi dapat diketahui kendala-kendala dan kekurangan yang dihadapi dalam kegiatan pembelajaran.b).Soal tes Berupa sejumlah soal test yang digunakan untuk mengukur presentasi belajar siswa. Selain itu juga digunakan untuk mengukur sejauh mana kemampuan siswa mendalami materi yang dipelajari dan untuk mengetahui kemajuan belajar siswa. Soal test digunakan saat pembelajaran yaitu dikerjakan secara berkelompok dan individu.c).Dokumentasi Untuk melihat nilai Aqidah Akhlak sebelum penerapan penelitian tindakan kelas, peneliti dapat mengetahui data-data dan informasi yang terkait dengan siswa sebagai pendukung penelitian. Dokumentasi juga menggambarkan situasi saat pembelajaran 
berlangsung.Indikator yang digunakan untuk mengukur peningkatan hasil belajar siswa adalah peningkatan hasil belajar siswa baik secara individual maupun klasikal serta ketuntasan belajar siswa. Secara klasikal keberhasilan 85\% sedangkan untuk nilai KKM 75. Teknik Analisis Data Untuk menganalisis tingkat keberhasilan atau persentase keberhasilan siswa setelah proses belajar mengajar setiap putarannya dilakukan dengan cara memberikan evaluasi berupa soal tes tertulis pada setiap akhir putaran dan melakukan pengematan terhadap aktivitas belajar siswa. Sehingga data yang diperoleh dari penelitian tindakan ini berupa data kuantitatif dan kualitatif yang kemudian diolah dengan menggunakan teknik pengolahan hasil test dan hasil observasi. Analisis dimulai dengan menganalisis data persiklus dan analisis antar siklus.Teknik yang digunakan dalam penelitian ini adalah teknik pengolahan hasil test yang akan dirinci dari data mentah yang diperoleh dari hasil test (pretest dan post-test) kemudian diolah melalui cara penyekoran, menilai setiap siswa, menghitung nilai rata-rata kemampuan siswa untuk mengetahui gambaran yang jelas mengenai hasil belajar dalam memahami pelajaran Akidah Akhlak.

\section{HASIL DAN PEMBAHASAN PENELITIAN}

\section{Analisis Data Pra Siklus}

Sebelum diadakan kegiatan pada siklus-siklus penelitian terlebih dulu diadakan tindakan pra siklus yang di ambil dari data nilai siswa mata pelajaran Akidah Akhlaq yang diperoleh dari nilai ulangan harian siswa pada materi iman kepada malaikat. Data pra siklus yang diambil setelah melaksanakan kegiatan belajar mengajar di siswa kelas VII B Madrasah Tsanawiyah Negeri 4 Paser dapat dilihat dari hasil nilai ulangan harian sebagaimana dapat dilihat dari tabel hasil nilai ulangan harian pada tabel 1 berikut :

Tabel 1. Rekapitulasi Nilai Ulangan Harian Siswa pada Pra Siklus

\begin{tabular}{|c|l|c|c|}
\hline No & \multicolumn{1}{|c|}{ Uraian } & Hasil & Persentase \\
\hline 1 & Jumlah siswa & 29 & $100 \%$ \\
\hline 2 & Jumlah siswa yang tuntas & 12 & $41 \%$ \\
\hline 3 & Jumlah siswa yang tidak tuntas & 17 & $59 \%$ \\
\hline 4 & Rata-rata nilai kelas & 70,3 & \\
\hline
\end{tabular}

Dari tabel rekapitulasi pra siklus diatas dapat disimpulkan bahwa kondisi awal kemampuan siswa pada mata pelajaran Akidah Akhlaq materi iman kepada malaikat, belum semua siswa dapat mencapai KKM. Adapun KKM yang ditentukan pada mata pelajaran Akidah Akhlaq adalah 75. Dari 29 siswa baru 12 atau $41 \%$ siswa yang mencapai KKM, sedangkan 17 atau $59 \%$ siswa lagi belum mencapai KKM sedangkan nilai rata-rata kelas 70,3.Secara klasikal belum tuntas karena persentase ketuntasan $41 \%$ atau kurang dari $85 \%$.Dengan hasil pengamatan kondisi awal siswa terhadap pembelajaran Akidah Akhlaq materi iman kepada malaikat, maka peneliti menyusun dan melaksanakan serangkaian perencanaan tindakan kelas guna mengatasi hambatan-hambatan tersebut, yang diakhiri pada sebuah kegiatan analisis atau refleksi.Pelaksanaan tindakan kelas disesuaikan dengan rencana pembelajaran yang telah dirumuskan sebelumnya dengan menerapkan strategi pembelajaran numbered Head Together meningkatkan hasil belajar siswa melalui tahapan-tahapan yang telah disiapkan.

\section{Analisis Data Siklus I}

Pada siklus I ini pembelajaran Akhidah Akhlaq dengan materi iman kepada malaikat menerapkan strategi pembelajaran Numbered Head Together.Dalam hal ini peneliti bertindak sebagai observer (pengamat). Pengamatan dibantu oleh rekan guru sejawat untuk menilai aspek-aspek yang terdapat pada lembar observasi guru dan lembar observasi siswa. Adapun proses belajar mengajar mengacu pada rencana pelaksanaan pembelajaran (RPP) yang telah disiapkan dan menggunakan instrumen penilaian berupa pre test dan post test serta lembar pengamatan guru dan siswa. Berikutdata hasil belajar siswa pada siklus I. Berikut ini adalah deskripsi data hasil Rekapitulasi Ketuntasan Siswa pada Siklus I Tabel2. 
Tabel 2. Rekapitulasi Ketuntasan Siswa pada Siklus I

\begin{tabular}{|c|l|c|c|}
\hline No & \multicolumn{1}{|c|}{ Uraian } & Hasil & Persentase \\
\hline 1 & Jumlah siswa & 29 & $100 \%$ \\
\hline 2 & Jumlah siswa yang tuntas & 22 & $76 \%$ \\
\hline 3 & Jumlah siswa yang tidak tuntas & 7 & $24 \%$ \\
\hline 4 & Rata-rata nilai kelas & 77,4 & \\
\hline
\end{tabular}

Dari data rekapitulasi hasil belajar siswa siklus I diatas, dapat diperoleh gambaran bahwa sebanyak 22 siswa atau $76 \%$ sudah mencapai Kriteria Ketuntasan Minimal (KKM) dan 7 siswa atau $24 \%$ belum mencapai kriteria minimal (KKM) Sedangkan rata-rata kelas mencapai 77.4.Secara klasikal belum tuntas karena dibawah 85\%yaitu $76 \%$.Dalam pelaksanaan siklus I selama proses pembelajaran dibutuhkan adanya pengamatan dari peneliti. Pengamatan ini meliputi: pertama, pengamatan terhadap guru selama melaksanakan proses pembelajaran, dan kedua, pengamatan terhadap siswa selama mengikuti proses pembelajaran. Berikut tabel pengamatan terhadap guru dan siswa dalam menerapkan model Numbered Head Together dalam proses pembelajara

\section{Analisis Data Siklus II}

Setelah pelaksanaan pemebelajaran siklus I selesai, peneliti melanjutkan ke siklus II. Peneliti bertindak sebagai observer (pengamat). Pengamatan dibantu oleh rekan guru sejawat untuk menilai aspek-aspek yang terdapat pada lembar pengamatan guru dan lembar pengamatan siswa. Adapun proses belajar mengajar mengacu pada rencana pelaksanaan pembelajaran (RPP) yang telah disiapkan dan menggunakan instrumen penilaian berupa pre test dan post test serta lembar pengamatan terhadap guru dan lembar pengamatan siswa. Berikut data hasil belajar siswa pada siklusII ( tabel 3)

Tabel 3. Rekapitulasi Ketuntasan Belajar Siswa pada Siklus II

\begin{tabular}{|l|l|c|c|}
\hline \multirow{2}{*}{ No } & \multicolumn{1}{|c|}{ Uraian } & Hasil & Persentase \\
\hline 1 & Jumlah siswa & 29 & $100 \%$ \\
\hline 2 & Jumlah siswa yang tuntas & 28 & $97 \%$ \\
\hline 3 & Jumlah siswa yang tidak tuntas & 1 & $3 \%$ \\
\hline 4 & Rata-rata nilai kelas & 85.40 & \\
\hline
\end{tabular}

Dari tabel rekapitulasi data ketuntasan belajar siswa diatas, dapat diperoleh gambaran siklus II ini menunjukkan adanya peningkatan dari hasil sebelumnya. Sebanyak 28 siswa atau 97\% sudah mencapai Kriteria Ketuntasan Minimal (KKM) Sedangkan rata-rata kelas mencapai 85,40 hasil tersebut menunjukan adanya peningkatan dari hasil sebelumnya. Dalam pelaksanaan siklus II ini dalam proses pembelajaran dibutuhkan adanya pengamatan dari peneliti. Pengamatan ini meliputi pengamatan terhadap guru dan pengamatan terhadap siswa selama proses pembelajaran berlangsung. Berikut tabel pengamatan terhadap guru dan siswa dalam menerapkan strategi Numbered Head Together dalam proses pembelajaran.

Tindakan penelitian ini dilakukan melalui 2 tahapan yaitu tahap siklus I dan siklus II yang diawali dengan tindakan pra siklus. Pembahasan hasil penelitian ini meliputi hasil tes formatif, pengamatan guru dan pengamatan siswa. Pada siklus I mengacu pada rencana pembelajaran yang telah disusun oleh peneliti. Pada awal pembelajaran, peneliti mengulas sedikit materi yang ada kaitannya dengan iman kepada malaikat yaitu pengertian dan sifatsifat malaikat beserta memberikan motivasi kepada peserta didik, di harapkan agar peserta didik dapat tertarik untuk mempelajari materi tersebut. Namun pada siklus I masih terdapat beberapa siswa bermain sendiri dan masih gaduh di dalam kelas ketika teman-teman yang lain sedang mengerjakan tugas yang diberikan oleh guru. Hal ini menunjukkan bahwa pembelajaran harus diperbaiki dan dilanjut dengan siklus II.

Proses pembelajaran siklus I yang dilakukan oleh peneliti adalah mengoptimalkan terjadinya 
interaksi antar peserta didik dengan guru sehingga proses pembelajaran tidak hanya berlangsung satu arah melalui kegiatan kelompok. Selama pembelajaran peneliti memberikan latihan- latihan soal yang harus dikerjakan oleh peserta didik secara berkelompok. Pelaksanaan diskusi kelompok bertujuan agar peserta didik lebih banyak berinteraksi dengan teman satu kelompok dalam menyelesaikan soal yang diberikan oleh guru kepada mereka, sehingga apabila mereka mengalami kesulitan dalam menyelesaikan soal tersebut dapat bertanya kepada teman satu kelompok. Namun apabila semua peserta didik dalam satu kelompokjuga tidak dapat menyelesaikan, maka peserta didik tersebut dapat bertanya kepada guru.Pemberian latihan soal dimulai dari soal tingkat kesulitan yang rendah ke soal tingkat kesulitan tinggi. Pada akhir pembelajaran, peneliti membimbing peserta didik untuk menarik kesimpulan dari apa yang telah mereka pelajari dan mengadakan evaluasi akhir siklus untuk mengetahui tingkat pemahaman peserta didik terhadap materi yang telah diajarkan. Pada tindakan siklus II ini proses pembelajaran lebih baik di bandingakan dengan siklus I .Pada siklus II perbaikan pembelajaran pada materi pengertian jin,iblis dan setan, membedakan jin,iblis dan setan dengan metode Numered Head Together. Pada siklus II siswa sudah memahami bagaimana jalannya proses pembelajaran Numbered Head Together. Terlihat siswa juga merasa senang dan aktif selama penugasan dilaksanakan sehingga hasil pembelajaran dan nlai rata-rata siswa menunjukkan adanya peningkatan. Hal tersebut dibuktikan dengan tercapainya hasil peningkatan belajar siswa secara klasikal sebesar 97\% yang pada kondisi awal hanya $41 \%$ sehingga proes perbaikan pembelajaran dinyatakan berhasil dan tuntas pada pelaksanaan siklus II.

Tabel 4. Perbandingan Hasil Belajar Siswa, Pra Siklus, Siklus I dan Siklus II

\begin{tabular}{|c|c|c|c|c|c|c|}
\hline \multirow[b]{2}{*}{ No } & \multirow[b]{2}{*}{ Tahap } & \multicolumn{5}{|c|}{ Hasil $\quad$ Belajar } \\
\hline & & $\begin{array}{c}\text { Rata-rata } \\
\text { Nilai }\end{array}$ & Tuntas & $\begin{array}{c}\text { Persentase } \\
\%\end{array}$ & $\begin{array}{c}\text { Tidak } \\
\text { Tuntas }\end{array}$ & $\begin{array}{c}\text { Persentase } \\
\%\end{array}$ \\
\hline 1 & Pra siklus & 71,3 & 12 & $41 \%$ & 17 & $59 \%$ \\
\hline 2 & Siklus I & 77,4 & 22 & $76 \%$ & 7 & $24 \%$ \\
\hline 3 & Siklus II & 85.40 & 28 & $97 \%$ & 1 & $3 \%$ \\
\hline
\end{tabular}

Berdasarkan tabel perbandingan hasil belajar siswa, dapat dinyatakan bahwa hasil evaluasi pembelajaran dari pra siklus, siklus I dan siklus II, dapat dijelaskan adanya peningkatan hasil belajar dari setiap tindakan. Banyak siswa yang berhasil untuk memenuhi Kriteria Ketuntasan Minimal (KKM) hampir semua mengalami peningkatan pada setiap siklusnya. Dapat dilihat dari nilai rata-rata hasil belajar siswa pada pra siklus sebesar 71,3 menjadi 77.4 pada siklus I dan meningkat lagi pada siklus II menjadi 85.40 Persentase ketuntasan pada pra siklus $41 \%$ (12 siswa), pada siklus I sebanyak 77,4\% (22 siswa), dan pada siklus II sebanyak 97\% (28 siswa). Secara klasikal peningkatan hasil belajar siswa sebesar 97\% yang pada kondisi awal hanya 41\%. Dari 29 siswa sudah mencapai Kriteria Ketuntasan Minimum (KKM).

Dari hasil penelitian menunjukan bahwa terdapat perbedaan hasil belajar siswa yang menggunakan model pembelajaran Numbered Head Together lebih optimal lebih menuntaskan hasil pemahaman siswa dibandingkan dengan metode ceramah.Dengan menggunakan model pembelajaran Numbered Head Together siswa menjadi lebih aktif. Menurut Hidayanti (2012) dengan menggunakan model pembelajaran Numbered Head Together dapat mencapai kualifikasi keefektifan yang ditentukan dan kemampuan pemahaman konsep menggunakan model pembelajaran Numbered Head Together lebih baik dibandingkan dengan metode pembelajaran ekspositori. Hasil belajar siswa dapat diukur dengan menggunakan alat evaluasi yang biasanya disebut tes hasil belajar sedangkan tingkat keberhasilan atau penguasaan seorang siswa terhadap materi setelah menempuh proses belajar mengajar yang terlihat pada nilai yang diperoleh dari tes hasil belajarnya.Menurut slameto (2013:2) belajar adalah suatu proses usaha yang dilakukan seseorang untuk memperoleh suatu perubahan tingkah laku yang baru secara keseluruhan.Sedangkan menurut Djamarah 
(2013:10)belajar adalah proses perubahan prilaku berkat pengalaman dan latihan.Kemampuan yang dimiliki siswa setelah mengikuti proses pembelajaran adalah hasil belajar.. Penilaian terhadap belajar siswa merupakan hal yang sangat penting dilakukan oleh guru setelah melaksanakan kegiatan belajar mengajar.hasil belajar siswa dapat dipenggaruhi beberapa faktor yaitu faktor intern dan faktor ekstern.Menurut Slameto,(2013:54-72) mengemukakan faktor yang mempenggaruhi hasil belajar terbagi dalam dua golongan : (1) faktor intern adalah faktor yang ada dalam diri individu yang sedang belajar, yang terdiri dari : (a) faktor jasmaniah; (b) faktor psikologis; (c) faktor kelelahan. (2) Faktor ekstern adalah faktor yang ada diluar individu.Peningkatan hasil belajar tersebut dipengaruhi faktor-faktor yang ada pada diri siswa dan dari luar yang peneliti upayakan dengan maksimal agar tujuan penelitian dapat tercapai. Beberapa siswa yang hasil belajarnya masih rendah dikarenakan beberapa faktor yaitu internal dari anak itu sendiri dan eksternal dari luar diri sendiri. Faktor internal yang mempengaruhi hasil belajar meliputi kecerdasan, minat dan perhatian, motivasi belajar dan ketekunan, sikap kebiasaan belajar, serta kondisi fisik dan kesehatan. Sedangkan faktor ekternal yang mempengaruhi hasil belajar siswa yaitu keluarga, sekolah dan masyarakat.Dua faktor ini sangat dominan dalam mempengaruhi hasil belajar .Hasil belajar Akidah Akhlak kelas VII B ini didukung dengan perhatian dan keaktifan siswa. Siswa yang tuntas dalam belajar adalah siswa yang memperhatikan, mendengarkan, aktif bertanya dan merespon serta antusias saat pembelajaran berlangsung maupun saat diadakannya tes/evaluasi. Keaktifan dan perilaku siswa yang semakin baik akan membawa perubahan yang berdampak positif bagi peningkatan hasil belajar Dengan demikian dapat dinyatakan bahwa penelitian tindakan kelas yang dilaksanakan di Kelas VII B Madrasah Tsanawiyah Negeri 4 Paser telah berhasil mencapai indikator keberhasilan yang telah ditetapkan yaitu $85 \%$. Sehingga hipotesis tindakan yang menyatakan "melalui model Numbered Head Together dapat meningkatkan hasil belajar Akidah Akhlak materi iman kepada malaikat pada siswa kelas VII B Madrasah Tsanawiyah Negeri 4 Paser tahun pelajaran 2019/2020.

\section{KESIMPULAN}

Berdasarkan hasil penelitian dan pembahasan tentang Upaya Meningkatkan Prestasi Belajar pada Pembelajaran Aqidah Akhlak Materi Pokok iman kepada malaikat. Melalui Model Pembelajaran Numbered Head Togther Kelas VII B Madrasah Tsanawiyah Negeri 4 Paser tahun 2019/2020, dapat peneliti kemukakan kesimpulan sebagai berikut:Ada peningkatan prestasi belajar peserta didik pada pembelajaran Akidah Akhlak materi iman kepada malaikat melalui model pembelajaran Numbered Head Together kelas VII B Madrasah Tsanawiyah Negeri 4 Paser 2019/2020.Dapat dilihat dengan adanya peningkatan hasil belajar mulai dari pra siklus dengan rata-rata 71,3 dengan presentasi ketuntasan $41 \%$. Pada siklus I dengan rata-rata 77.4 dengan presentase ketuntasan $76 \%$ dan siklus II meningkat menjadi rata-rata 85,40 dengan presentase ketuntasan 97\%. Untuk angka ketuntasan hasil belajar siswa pada pra siklus sebanyak 12 anak atau sebesar $41 \%$ meningkat menjadi 22 anak atau sebesar $76 \%$ pada siklus I dan menjadi 28 anak atau sebesar 97\% pada siklus II. Jadi angka ketuntasan belajar dari pra siklus sampai siklus II meningkat sebanyak 16 anak atau sebesar 55\%. Hal ini menunjukkan bahwa hasil belajar siswa tersebut telah memenuhi Kriteria Ketuntasan Minimal yaitu 75 dan Ketuntasan KKM kelas 85\% yang demikian menunjukkan bahwa ada peningkatan hasil belajar peserta didik.

\section{DAFTAR PUSTAKA}

Anita,Lie, 2004. Cooperative Learning. Jakarta: Grasindo.

Arikunto. Suharsimi. (2006). Prosedur Penelitian: Suatu Pendekatan Praktik. Jakarta: PT.

Rineka Cipta

Djamarah, Syaiful Bahri. (2013). Strategi Belajar Mengajar,Jakarta : PT Rineka Cipta

Hidayanti, Rini. 2012. Kefektifan pembelajaran koooperatif Numbered Head Together terhadap puan pemahaman konsep. Dalam jurnal pendidikan matematika, Volume 1 
no 1 hal 58-64 Semarang: UNNES

Muslimin, Ibrahim. 2000.Pembelajaran Kooperatif. Surabaya: University Press

PERMENAG RI. No.2 Tahun 2008. Tentang Standar Isi. Jakarta:

Slameto. (2013). Belajar dan Faktor-faktor yang Mempengaruhi Jakarta : PT Rineka Cipta

Sudjana, Nana. (2006). Penilaian Hasil Proses Belajar Mengajar. Bandung: PT

RemajaRosdakarya.

Suprijono, Agus. (2010). Cooperative Learning Teori dan Aplikasi Paikem.Surabaya: Pustaka Pelajar.

Suyadi.(2010). Panduan Penelitian Tindakan Kelas. Yogyakarta: Diva Press.

Susanto, Ahmad. (2012). Teori Belajar dan Pembelajaran di Sekolah Dasar.Jakarta:

Kencana

Prenada Media Group.

Trianto. 2007. Model Pembelajaran Inovatif Berorientasi Konstruktivistik. Jakarta: Prestasi Pustaka.

Uno Dkk, Menjadi Peneliti PTK Yang Professional,(Jakarta:PT Bumi Aksara,2011) 